\title{
Sensitivity of Populations of Botrytis cinerea from Pear-Related Sources to Benzimidazole and Dicarboximide Fungicides
}

Cheryl L. Lennox, ARC-Plant Protection Research Institute, Private Bag X5017, Stellenbosch 7599, South Africa; and Robert A. Spotts, Oregon State University Mid-Columbia Agricultural Research and Extension Center, 3005 Experiment Station Drive, Hood River 97031

\begin{abstract}
Lennox, C. L., and Spotts, R. A. 2003. Sensitivity of populations of Botrytis cinerea from pearrelated sources to benzimidazole and dicarboximide fungicides. Plant Dis. 87:645-649.

Botrytis cinerea is responsible for a major portion of postharvest decay in winter pears in the Pacific Northwest. The baseline sensitivity levels (mean $\mathrm{EC}_{50}$ values) of a wild-type $B$. cinerea population to thiabendazole and iprodione were 6.66 and $0.56 \mathrm{mg} /$ liter, respectively. B. cinerea from commercial orchards not treated with a benzimidazole had significantly lower incidence of resistance $(0.59 \%)$ to a discriminatory concentration of thiabendazole at $10 \mathrm{mg} / \mathrm{liter}$ than did isolates from orchards in which benomyl had been applied for experimental purposes $(16.0 \%)$, unsprayed control trees in benomyl-sprayed orchards (5.34\%), and isolates from packinghouses where thiabendazole was applied as a prestorage drench or packingline spray $(3.23 \%)$. The mean $\mathrm{EC}_{50}$ value of isolates in the wild-type population was lower than those of resistant isolates from all other sources. High-level thiabendazole resistance $\left(\mathrm{EC}_{50}>100 \mathrm{mg} / \mathrm{liter}\right)$ was found in $0.20 \%$ of isolates from unsprayed commercial orchards, $9.33 \%$ of isolates from benomyl-sprayed orchards, and $2.67 \%$ of isolates from unsprayed control trees in these benomylsprayed orchards. In isolates from packinghouses where a thiabendazole line spray was applied, $1.52 \%$ had high-level thiabendazole resistance. All isolates from all pear-related sources tested were sensitive to iprodione at $10 \mathrm{mg} /$ liter. This study provides evidence supporting current recommendations of a single postharvest application of a benzimidazole to control decay caused by B. cinerea, and no application of benzimidazole fungicides in the orchard.
\end{abstract}

Additional keywords: gray mold, Pyrus communis

The largest volume of winter pears for fresh consumption in the United States is grown and shipped from packinghouses in Washington and Oregon (13). A survey of the major pear packinghouses in Washington and the mid-Columbia region of Oregon for the 1991 to 1993 pear crop estimated a postharvest decay loss of $\$ 2.4$ million per year, with 22 of the 30 packers surveyed considering decay as the most serious problem (14). In a survey of culled pear fruit conducted by the authors in four packinghouses for the period 1994 to 1996, Botrytis cinerea Pers.:Fr. caused 55\% of the total decay, whereas Penicillium spp. and Mucor piriformis were responsible for 24 and $8 \%$, respectively. The remaining $13 \%$ was ascribed to other pathogens, including Cladosporium, Alternaria, and Pezicula spp. (15). From the time of introduction of benzimidazole fungicides in the early 1970s, their effectiveness against decay of pome fruit caused by $B$. cinerea was recognized $(5,7)$. Initially, postharvest

Corresponding author: C. L. Lennox

E-mail: vredcl@plant3.agric.za

Accepted for publication 6 January 2003.

Publication no. D-2003-0324-02R

(C) 2003 The American Phytopathological Society losses in the pear industry were reduced to insignificance; however, by 1975 benomylresistant strains of $P$. expansum and $B$. cinerea were found in Oregon and Washington (6).

Current control measures aimed at reducing decay include a preharvest application of ziram, dump tank and flume water sanitation with chlorine or sodium $o$ phenylphenate, and either a postharvest drench or packingline spray application of the benzimidazole thiabendazole (1). The pear-packing industry of the Pacific Northwest is singularly dependent on fungicides from this class to control decay.

The objectives of this research were (i) to determine the baseline sensitivity levels to thiabendazole and the dicarboximide fungicide iprodione of a wild-type $B$. cinerea population from an abandoned pear orchard that had not been subjected to the selection pressure of fungicide applications, and (ii) to determine the influence of fungicide application in the orchard and packinghouse on sensitivity of $B$. cinerea isolates.

\section{MATERIALS AND METHODS}

Fungicides and media. Commercially formulated fungicides were used in this study. Thiabendazole (Mertect 340 F, Syngenta Crop Protection, Greensboro, NC) was selected to represent the benzimida- zole class of fungicides currently used in packinghouses throughout the Pacific Northwest. Although dicarboximide fungicides have never been used in pear orchards or packinghouses in the Pacific Northwest, dicarboximides are used to control brown rot in cherry orchards, which often are close to pear orchards. Iprodione (Rovral 50 WP, Aventis Crop Science, Research Triangle Park, NC) was selected to represent the dicarboximide fungicides. Fungicide-amended medium was prepared by adding fungicide from an aqueous stock solution to sterile potato dextrose agar (PDA) (Difco Laboratories, Detroit, MI) at $50^{\circ} \mathrm{C}$. The amended agar was thoroughly mixed and dispensed into 100-mm-diameter polystyrene petri dishes. All concentrations are given as active ingredient.

Collection of $B$. cinerea isolates. $B$. cinerea was isolated from pear blossoms and fruit collected from an abandoned orchard that had not been subjected to fungicide selection pressure for at least 20 years. Blossoms were incubated on moist paper towels in sterile plastic boxes in a laboratory at $22^{\circ} \mathrm{C}$ under diurnal light and examined daily for signs of the fungus. Single conidiophores were transferred to petri dishes containing PDA acidified with $1 \mathrm{ml}$ of lactic acid (80\%) per liter (APDA). Fruits collected from the abandoned orchard were packed into cardboard fruit boxes lined with a polyethylene liner. The fruits were stored at $22^{\circ} \mathrm{C}$ for 7 days and examined for symptoms of decay caused by $B$. cinerea. Infected fruits were surface sterilized in $70 \%$ ethanol for $30 \mathrm{~s}, 0.35 \%$ sodium hypochlorite for $2 \mathrm{~min}$, and $70 \%$ ethanol for $30 \mathrm{~s}$. Fruit were allowed to airdry in a laminar air flow cabinet. Sections of fruit tissue $\left(5 \mathrm{~mm}^{2}\right)$ from the margins of decayed tissue were transferred to petri dishes containing APDA and incubated at $22^{\circ} \mathrm{C}$ under diurnal light. B. cinerea from both blossoms and fruit was transferred onto APDA. Identification of $B$. cinerea was verified by examination under a compound microscope. Pure subcultures of $B$. cinerea were stored on PDA slants at $5^{\circ} \mathrm{C}$ in the dark. A total of $126 \mathrm{~B}$. cinerea isolates were collected from fruit in the abandoned orchard.

In vitro assay to determine baseline sensitivity to benzimidazole and dicarboximide of a wild-type $B$. cinerea population. For rapidly growing facultative 
parasites like $B$. cinerea, the in vitro colony radial growth assay is considered the most appropriate (22). The sensitivity levels of $126 \mathrm{~B}$. cinerea isolates from the abandoned orchard were determined by conducting mycelial growth tests for each isolate on PDA amended with thiabendazole or iprodione. Each isolate was grown on nine concentrations of each fungicide, 0 (unamended control), 0.05, 0.1, 0.5, 1, 3, 5, 10 , and $25 \mathrm{mg}$ a.i./liter. Mycelial plugs (5 $\mathrm{mm}$ diameter) of each isolate were removed from the actively growing colony margins and placed inverted in the center of petri dishes containing the fungicide concentrations, with three plates per concentration. The cultures were incubated for $36 \mathrm{~h}$ at $22^{\circ} \mathrm{C}$ in the dark. Following the method used by Northover and Matteoni (19), mean radial growth of colonies was determined by measurements made at right angles. Mean radial growth of colonies at each concentration of fungicide was expressed as a percentage of the mean radial growth on unamended PDA and subtracted from 100 to give percent inhibition. The linear regression of percent inhibition (nontransformed) with fungicide concentration (most appropriate transformation for the particular isolate) was examined for each replicate series of each isolate. The fungicide concentration that inhibited colony growth of the isolates by $50 \%\left(\mathrm{EC}_{50}\right.$ value) compared with the control was derived from the regression equation.

Isolation of $B$. cinerea from pearrelated sources. $B$. cinerea isolates were collected from several pear-related sources over a 4-year period. During 1997 to 1998, air samples were collected monthly from 14 commercial pear orchards onto petri dishes containing APDA using a portable air sampler for agar plates (Burkard Manufacturing Co., Ltd., Hertfordshire, UK; patent no. 8819423.8). Fruit from these 14 orchards were picked at commercial harvest and stored either with or without a prestorage thiabendazole drench or line spray at a commercial packinghouse. After cold storage up to 6 months, fruit from these orchards were examined for decay caused by $B$. cinerea. Isolates of $B$. cinerea were collected as described above for isolations made from fruit from the abandoned orchard. In February 1998, coldstored pear fruit showing signs of decay caused by $B$. cinerea were collected from packinghouses in both Oregon (Hood River and Medford) and Washington (Mt Adams, Wenatchee, Levenworth, and Yakima). Records were made of whether or not the fruit had received a prestorage benzimidazole application. Isolates of $B$. cinerea were collected as described for fruit from the abandoned orchard above. During the pear-growing seasons of 1996 and 1997, the benzimidazole fungicide benomyl (Benlate $50 \mathrm{WP}$ ) was applied for experimental purposes in three 'd'Anjou' pear orchards. Three replicate trees in each orchard were sprayed once every 2 weeks with benomyl at $0.45 \mathrm{~g} /$ liter and 1,893 liters/ha. Blossoms and the floral components of the calyx ends of fruit from both sprayed trees and unsprayed control trees in these three orchards were regularly plated onto a Botrytis-selective medium (12). Fruit from these three orchards were stored in air at $-1^{\circ} \mathrm{C}$ and did not receive a drench or line spray of thiabendazole. After 8 months in storage, fruit were examined for decay caused by $B$. cinerea. Isolates of

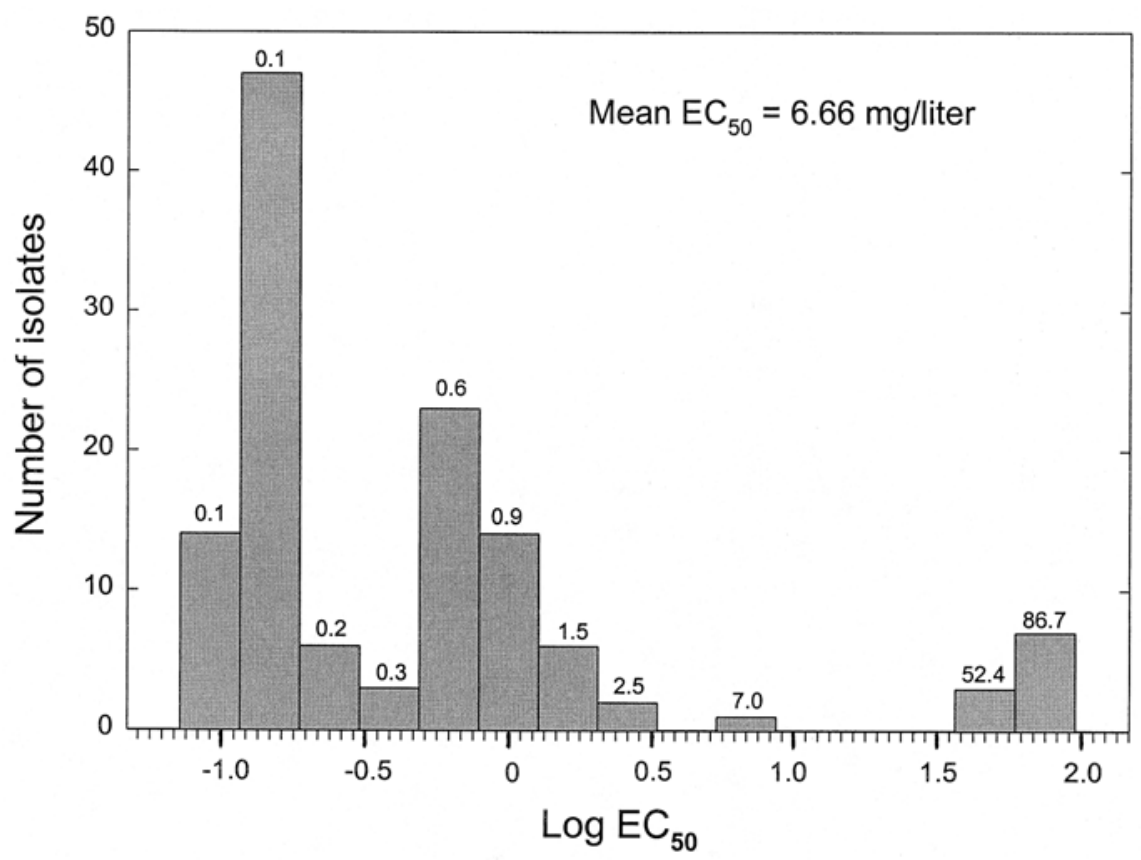

Fig. 1. Frequency distribution of $\mathrm{EC}_{50}$ values to thiabendazole determined for isolates of Botrytis cinerea from an abandoned pear orchard that had not been subjected to fungicide selection pressure for 20 years. Numbers above bars are mean $\mathrm{EC}_{50}$ values in $\mathrm{mg} / \mathrm{liter}$.
$B$. cinerea were collected as described above. All B. cinerea isolates were transferred onto APDA before being stored on PDA slants at $5^{\circ} \mathrm{C}$ in the dark.

Monitoring for benzimidazole and dicarboximide resistance in $B$. cinerea isolates. Resistance to benzimidazole and dicarboximide fungicides in the $B$. cinerea isolates was determined according to protocols of the Fungicide Resistance Action Committee (FRAC) (17,22). The mycelial growth sensitivity of the isolates to thiabendazole and iprodione was determined on PDA amended with a discriminatory concentration of $10 \mathrm{mg} / \mathrm{liter}$ thiabendazole or iprodione. Mycelial plugs (5 $\mathrm{mm}$ diameter) from colony margins of the isolates were placed inverted in the center of each of three petri dishes containing either thiabendazole, iprodione, or unamended PDA. The cultures were incubated for $36 \mathrm{~h}$ at $22^{\circ} \mathrm{C}$ in the dark, and radial growth was determined. Isolates were designated resistant if they grew on the control (unamended) and fungicide-amended agar. Sensitive isolates did not grow on the fungicide-amended agar.

For comparative purposes, $B$. cinerea isolates collected from the various pearrelated sources were placed into five groups: a group of isolates from the abandoned pear orchard that had not been subjected to fungicide selection pressure for over 20 years; isolates from air, blossoms, and fruit from commercial pear orchards that had not been subjected to benzimidazole fungicide pressure; isolates from blossoms and fruit from the unsprayed control trees of an orchard that had been sprayed with benomyl; isolates from blossoms and fruit from the trees of an orchard that had been sprayed with benomyl; and isolates from pear fruit that had received a standard prestorage thiabendazole drench or line spray. Comparisons of resistance frequencies were made using the chi-square test (24). The $\mathrm{EC}_{50}$ values of all isolates resistant to either thiabendazole or iprodione at $10 \mathrm{mg} /$ liter were determined using the method described above; however, the fungicide concentration series was expanded to include the fungicide at 100 $\mathrm{mg} / \mathrm{liter}$.

\section{RESULTS}

Baseline sensitivity to benzimidazole and dicarboximide of a wild-type $B$. cinerea population. The mean $\mathrm{EC}_{50}$ value of $126 \mathrm{~B}$. cinerea isolates collected from the abandoned pear orchard on thiabendazole-amended PDA was $6.66 \mathrm{mg} / \mathrm{liter}$ with a standard error of 1.95 , and ranged from 0.06 to $>25 \mathrm{mg} / \mathrm{liter}$ (Fig. 1). The abandoned orchard population was considered to be indicative of a wild-type population; thus the mean $\mathrm{EC}_{50}$ value of $6.66 \mathrm{mg} / \mathrm{liter}$ represented the baseline sensitivity of the wild-type population to thiabendazole. A discriminatory concentration of $10 \mathrm{mg}$ of thiabendazole per liter was used for testing 
of resistance. For iprodione, the mean $\mathrm{EC}_{50}$ value was $0.56 \mathrm{mg} / \mathrm{liter}$ with a standard error of 0.30 and a range of 0.07 to 6.09 mg/liter (Fig. 2). A discriminatory concentration of $10 \mathrm{mg}$ of iprodione per liter was used (17) for subsequent assays.

Fungicide sensitivity survey. Based on a discriminatory concentration of $10 \mathrm{mg}$ of thiabendazole per liter, resistant isolates were detected from all pear-related sources (Table 1). No isolates from any pearrelated source grew on media amended with the discriminatory dose of $10 \mathrm{mg}$ of iprodione per liter; thus all isolates were considered to be sensitive to iprodione.

Isolates of $B$. cinerea from commercial orchards not subjected to a benzimidazole treatment had significantly lower incidence of resistance $(0.59 \%)$ than isolates from benomyl-sprayed orchards $(16.0 \%)$, unsprayed control trees in benomyl-sprayed orchards $(5.34 \%)$, and isolates from packinghouses where thiabendazole was applied as a prestorage drench or line spray

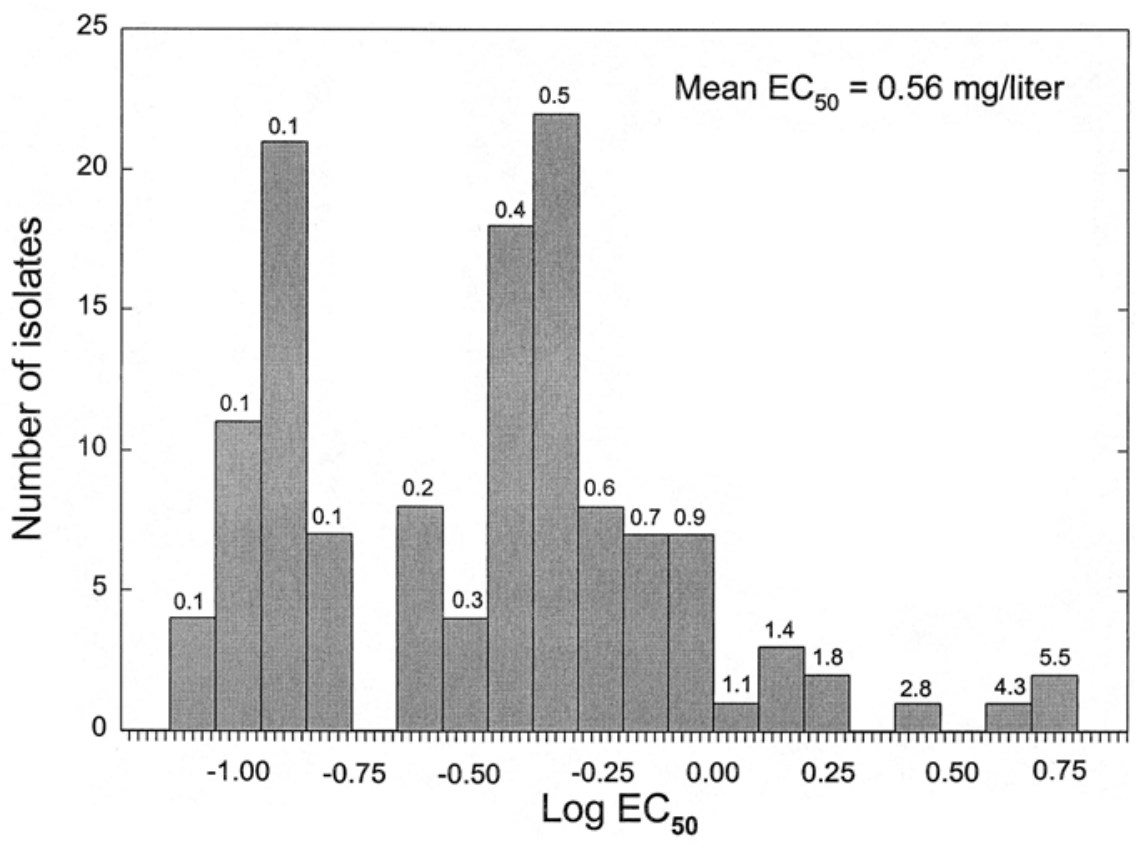

Fig. 2. Frequency distribution of $\mathrm{EC}_{50}$ values to iprodione determined for isolates of Botrytis cinerea from an abandoned pear orchard that had not been subjected to fungicide selection pressure for 20 years. Numbers above bars are mean $\mathrm{EC}_{50}$ values in $\mathrm{mg} /$ liter.
$(3.23 \%)$ (Table 1). Incidence of resistance in isolates from benomyl-sprayed orchards was significantly higher $(16.0 \%)$ than in isolates from unsprayed control trees in these orchards $(5.34 \%)$, or in isolates from packinghouses where a thiabendazole drench or line spray was applied $(3.23 \%)$ (Table 1). Resistance frequency in isolates from unsprayed control trees in benomylsprayed orchards $(5.33 \%)$ did not differ significantly from isolates from packinghouses where thiabendazole was applied $(3.23 \%)$ (Table 1).

High-level thiabendazole resistance $\left(\mathrm{EC}_{50}>100 \mathrm{mg} / \mathrm{liter}\right)$ was found in $0.20 \%$ of isolates from unsprayed commercial orchards, $9.33 \%$ of isolates from benomyl-sprayed orchards, and $2.67 \%$ of isolates from unsprayed control trees in the benomyl-sprayed orchards. In isolates from packinghouses where a thiabendazole line spray was applied, $1.52 \%$ had high-level thiabendazole resistance (Table 1$)$.
Isolates from the abandoned orchard had a mean $\mathrm{EC}_{50}$ value of $6.66 \mathrm{mg}$ of thiabendazole per liter. The mean $\mathrm{ED}_{50}$ value of resistant isolates from commercial orchards not exposed to benzimidazole was $48.56 \mathrm{mg} / \mathrm{liter}$. Mean $\mathrm{EC}_{50}$ values of isolates from unsprayed control trees in benomyl-sprayed orchards, benomyl-sprayed trees, and fruit subjected to a prestorage thiabendazole drench or packingline spray were $99.83,>100$, and $>100 \mathrm{mg} / \mathrm{liter}$, respectively (Table 1).

\section{DISCUSSION}

Benzimidazole resistance has been found in $B$. cinerea from a range of crops where this class of fungicide has been intensively used and resistance development resulting in loss of disease control can occur after only a few seasons of use $(8,16)$. In general, benzimidazole-resistant strains are just as fit as benzimidazolesensitive strains and can be found in the population even after the removal of selection pressure from the fungicide $(4,16,18)$. Despite severe resistance problems in many fungi, benzimidazoles are still widely used due to their broad spectrum of activity $(11,20)$.

The dicarboximides have been used to control B. cinerea in areas where high levels of benzimidazole resistance occur (18). Dicarboximides have not been used in pome fruit production in the Pacific Northwest, either in the orchard or in the packinghouse; however, fungicides from this class are used in cherry orchards that may be in close proximity to pear orchards. In the present study, all $B$. cinerea isolates were sensitive to thiabendazole at 10 $\mathrm{mg} / \mathrm{liter}$.

The sensitivity distribution of the $B$. cinerea population from the abandoned orchard indicated that this population was sensitive to both thiabendazole and iprodione, and we consider this population as representative of a wild-type (sensitive) population. The development and stability of fungicide resistance in $B$. cinerea populations has influenced control measures adopted by growers.

Screening for benzimidazole resistance in pear-related sources in the Pacific

Table 1. Sensitivity to thiabendazole of Botrytis cinerea isolates from air, blossoms, and fruit from pear orchards in Oregon and Washington

\begin{tabular}{|c|c|c|c|c|c|c|}
\hline \multirow[b]{2}{*}{ Source of isolates } & \multirow{2}{*}{$\begin{array}{l}\text { No. of } \\
\text { isolates }\end{array}$} & \multirow{2}{*}{$\begin{array}{c}\text { Isolates with } \mathrm{EC}_{50} \\
\text { between } 10 \text { and } 100 \\
\text { mg/liter }(\%)\end{array}$} & \multirow{2}{*}{$\begin{array}{c}\text { Isolates with } \mathrm{EC}_{50} \\
>100 \mathrm{mg} / \mathrm{liter} \\
(\%)\end{array}$} & \multirow[b]{2}{*}{$\mathbf{r}^{\mathrm{y}}(\%)$} & \multicolumn{2}{|c|}{$\mathbf{E C}_{50}$ value $^{\mathrm{z}}(\mathrm{mg} /$ liter $)$} \\
\hline & & & & & Mean & Range \\
\hline Abandoned orchard & 126 & & & & 6.66 & $0.06->25$ \\
\hline $\begin{array}{l}\text { Air and commercial orchards, no thiaben- } \\
\text { dazole }\end{array}$ & 510 & 0.39 & 0.20 & $0.59 \mathrm{a}$ & 48.56 & $13.26->100$ \\
\hline $\begin{array}{l}\text { Unsprayed controls of benomyl-sprayed } \\
\text { orchard }\end{array}$ & 75 & 2.67 & 2.67 & $5.34 \mathrm{bc}$ & 99.83 & $12.19->100$ \\
\hline Benomyl-sprayed trees & 75 & 6.67 & 9.33 & $16.00 \mathrm{~d}$ & $>100$ & $56.25->100$ \\
\hline $\begin{array}{l}\text { Commercial fruit treated with a prestorage } \\
\text { thiabendazole drench or line spray }\end{array}$ & 527 & 1.71 & 1.52 & $3.23 \mathrm{~b}$ & $>100$ & $70.31->100$ \\
\hline
\end{tabular}

y Total percentage of isolates that grew on potato dextrose agar amended with thiabendazole at $10 \mathrm{mg} /$ liter. Percentages of resistant isolates followed by different letters are significantly different at $P=0.05$.

${ }^{\mathrm{z}}$ Mean thiabendazole concentration that inhibited mycelial colony growth by $50 \%$. 
Northwest was initiated in 1975 (6). At that time, it was found that $33 \%$ of the $P$. expansum and $3 \%$ of $B$. cinerea isolates were resistant to $100 \mathrm{mg}$ of benomyl per liter in both 1975 to 1976 and 1976 to 1977. Spotts and Cervantes (23), taking samples from the same packinghouses as Bertrand and Saulie-Carter (6), found that benomyl resistance in Penicillium spp. had not increased during the 5-year interval. The percentages of $B$. cinerea isolates resistant to benomyl in 1981 to 1982 were $6 \%$ in air and dump water and $16 \%$ in fruit, and in 1982 to 1983 were $0 \%$ in air and dump water and $15 \%$ in fruit. B. cinerea isolates collected from fruit in 1983 to 1984 had a $35 \%$ incidence of resistance to benomyl.

In the present study, isolates were collected from the same commercial pear orchards and as those used by Bertrand and Saulie-Carter (6) and Spotts and Cervantes (23). We found $0.59 \%$ of isolates from unsprayed commercial orchards were resistant to thiabendazole, with $0.2 \%$ of isolates having high-level resistance $\left(\mathrm{EC}_{50}>100\right.$ $\mathrm{mg} / \mathrm{liter}$ ). Isolates from commercial fruit that received a single prestorage thiabendazole drench or line spray had a significantly higher incidence of resistance $(3.23 \%)$, with $1.52 \%$ of isolates having high-level resistance. In addition, the mean $\mathrm{EC}_{50}$ value of isolates from the commercial orchards was higher than that of the abandoned orchard population, indicating that orchard management practices place some selection pressure on the $B$. cinerea population. Incidence of resistance in isolates from unsprayed commercial orchards was significantly lower than incidence in populations exposed to benzimidazole selection pressure either in the form of preharvest benomyl orchard applications or a prestorage thiabendazole drench or line spray.

Indications of high selection pressure created by orchard applications of benzimidazoles and high mobility of $B$. cinerea in the orchard (4) are twofold: the incidence of resistant isolates from orchards where benomyl was applied was higher than from the air and fruit of commercial orchards not exposed to benzimidazoles and from sources subjected to a single application of thiabendazole in the packinghouse; and the incidences of resistant isolates from unsprayed control trees and from benomyl-treated trees in the benomyl-treated orchards were not significantly different, but were significantly higher than those from sources not subjected to any benzimidazole. In this study, application of benomyl in the orchard increased the incidence of resistance to thiabendazole in vitro, providing further evidence for cross-resistance between benzimidazoles.

One to three preharvest sprays with benomyl or thiabendazole provide excellent control of postharvest decay in pears caused by $B$. cinerea $(3,5,21)$. Good control of $B$. cinerea also can be achieved through a single postharvest application of a benzimidazole to pear fruit in the packinghouse $(2,5,9)$. In addition, a single postharvest application subjects the population of $B$. cinerea to a lower selection pressure since isolates from orchards sprayed with benomyl had the greatest incidence of resistant isolates.

No cross-resistance has been reported between benzimidazoles and dicarboximides (18), which reflects the very different modes of action of these fungicides. Resistance in $B$. cinerea isolates to both benzimidazoles and dicarboximides (double or dual resistance) has been observed in a variety of crops $(4,18,29)$. This frequently has been explained on the basis that benzimidazole-resistant strains were abundant at the time of dicarboximide introduction. The absence of dual resistance in this study is either a reflection of the very low selection pressure for dicarboximide resistance in the commercial pear orchards and packinghouses of the Pacific Northwest, or an indication that low-level resistance (4) to iprodione was not detected by our use of $10 \mathrm{mg} / \mathrm{liter}$ as a discriminatory concentration.

Although $B$. cinerea populations in commercial orchards were sensitive to the benzimidazoles, a single application of a benzimidazole in the packinghouse increased the incidence of resistance significantly. In practice, however, because selection pressure would be applied at the end of the production line, decayed fruit that include resistant isolates would be culled and removed from the population. Application of a benzimidazole in the orchard, however, would put a severe selection pressure on the $B$. cinerea population, even affecting isolates in nearby unsprayed trees. Consequently, fruit coming into the packinghouse would have higher levels of resistant $B$. cinerea isolates (both as established latent infections and as inoculum on the fruit surface). Subsequent application of a benzimidazole as a postharvest treatment would not be as effective for decay control. Cross-resistance has been shown for all benzimidazole fungicides, and this scenario would apply irrespective of the benzimidazole applied in the orchard.

A well-recognized method for reducing the selection pressure of a compound is to restrict its use to one or two critical periods (28). This study provides evidence supporting current postharvest decay control recommendations that include avoiding the use of benzimidazole fungicides in the orchard and a single postharvest application of a benzimidazole to control decay caused by $B$. cinerea. Most growers apply a preharvest contact fungicide such as ziram to reduce populations of $B$. cinerea on fruit surfaces. Use of a preharvest contact fungicide and a postharvest systemic benzimidazole fungicide under the current level of sensitivity of the $B$. cinerea population in commercial orchards, in concert with good orchard and packinghouse man- agement practices $(1,26)$, should provide adequate control of postharvest decay caused by $B$. cinerea. An integrated approach to postharvest disease control and evidence of successful use of biological control agents to reduce postharvest diseases of pome fruit $(10,25,27)$ will contribute greatly to efforts to reduce fungicide selection pressure in populations of $B$. cinerea.

\section{ACKNOWLEDGMENTS}

We thank M. Booyse, ARC-Agrimetric Institute, South Africa, for statistical analysis of data and the Winter Pear Control Committee for partial funding of the research. Use of trade names in this article does not imply endorsement by Oregon State University of the products named or criticism of similar products not mentioned. Oregon Agricultural Experiment Station technical paper 11881.

\section{LITERATURE CITED}

1. Anonymous 1992. Management practices to minimize postharvest decay of apples and pears. Tree Fruit Postharvest J. 3:5-8.

2. Banyal, D. K., and Sharma, R. L. 1994. Effect of postharvest fungicidal treatments on grey mould rot of pear caused by Botrytis cinerea. Plant Dis. Res. 9:172-174.

3. Banyal, D. K., and Sharma, R. L. 1996. Efficacy of pre-harvest fungicidal sprays on gray mold rot and fruit quality of pear in storage. Indian J. Mycol. Plant Pathol. 26:286-288.

4. Beever, R. E., Laracy, E. P., and Pak, H. A. 1989. Strains of Botrytis cinerea resistant to dicarboximide and benzimidazole fungicides in New Zealand vineyards. Plant Pathol. 38:427-437.

5. Ben-Arie, R., and Guelfat-Reich, S. 1973. Preharvest and postharvest applications of benzimidazoles for control of storage decay of pears. HortScience 8:181-183.

6. Bertrand, P. F., and Saulie-Carter, J. L. 1978. The occurrence of benomyl-tolerant strains of Penicillium expansum and B. cinerea in the Mid-Columbia region of Oregon and Washington. Plant Dis. Rep. 62:302-305.

7. Blanpied, G. D., and Purnasiri, A. 1970 Thiabendazole control of postharvest apple decay. HortScience 5:476-478.

8. Bollen, G. J., and Scholten, G. 1971. Acquired resistance to benomyl and some other systemic fungicides in a strain of Botrytis cinerea in cyclamen. Neth. J. Plant Pathol. 77:83-90.

9. Chand-Goyal, T., and Spotts, R. A. 1996 Control of postharvest pear diseases using natural saprophytic yeast colonists and their combination with a low dosage of thiabendazole. Postharvest Biol. Technol. 7:51-64.

10. Chand-Goyal, T., and Spotts, R. A. 1997. Biological control of postharvest diseases of apple and pear under semi-commercial and commercial conditions using three saprophytic yeasts. Biol. Control 10:199-206.

11. Delp, C. J. 1995. Benzimidazoles and related fungicides. Pages 291-303 in: Modern Selective Fungicides - Properties, Applications, Mechanisms of Action. 2nd ed. H. Lyr, ed. Gustav Fisher Verlag, Stuttgart, Germany.

12. Kerssies, A. 1990. A selective medium for Botrytis cinerea to be used in a spore-trap. Neth. J. Plant Pathol. 96:247-250.

13. Kupferman, E. 1995. Postharvest handling of Anjou pears. Tree Fruit Postharvest J. 6:3-8

14. Kupferman, E. 1995. Practices to reduce postharvest pear diseases. Tree Fruit Postharvest J. 6:18-23.

15. Lennox, C. L., and Spotts, R. A. 1997. Botry- 
tis gray mold as a postharvest pathogen in d'Anjou pear. Pages 93-95 in: Proc. Annu. Washington Tree Fruit Postharvest Conf., 13th. E. Kupferman, ed. Washington State Horticultural Association, Wenatchee.

16. Leroux, P., and Clerjeau, M. 1985. Resistance of Botrytis cinerea Pers. and Plasmopara viticola (Berk. \& Curt.) Berl. and de Toni to fungicides in French vineyards. Crop Prot. 4:137160.

17. Löcher, F. J., and Lorenz, G. 1991. Methods for monitoring the sensitivity of Botrytis cinerea to dicarboximide fungicides. Pages 341345 in: FRAC Methods for Monitoring Fungicide Resistance. EPPO Bull. 21.

18. Lorenz, G. 1988. Dicarboximide fungicides: History of resistance development and monitoring methods. Pages 45-51 in: Fungicide Resistance in North America. C. J. Delp, ed. American Phytopathological Society, St Paul, $\mathrm{MN}$.

19. Northover, J., and Matteoni, J. A. 1986. Resistance of Botrytis cinerea to benomyl and iprodione in vineyards and greenhouses after exposure to the fungicides alone or mixed with captan. Plant Dis. 70:398-402.

20. Russel, P. E. 1995. Fungicide resistance: Occurrence and management. J. Agric. Sci. 124:317-323.

21. Sharma, R. L. 1990. Efficacy of preharvest fungicidal sprays in controlling postharvest diseases of China pear. Plant Dis. Res. 5:109111.

22. Smith, C. M., Trivellas, A. E., Johnson, L. E. B., and Joshi, M. M. 1991. Methods for monitoring the sensitivity of a range of fungal pathogens to benzimidazole fungicides. Pages 336-341 in: FRAC Methods for Monitoring Fungicide Resistance. EPPO Bull. 21.

23. Spotts, R. A., and Cervantes, L. A. 1986. Populations, pathogenicity, and benomyl resistance of Botrytis spp., Penicillium spp., and Mucor piriformis in packinghouses. Plant Dis. 70:106108.

24. Steel, R. G. D., Torrie, J. H., and Dickey, D. A. 1997. Principles and Procedures of Statistics: A
Biometric Approach. McGraw-Hill, New York. 25. Sugar, D., Richardson, D. G., Chen, P. M. Spotts, R. A., Roberts, R. G., and ChandGoyal, T. 1998. Advances in improving the postharvest quality of pears. Acta Hortic. 475:513-526

26. Sugar, D., and Spotts, R. A. 1995. Preharvest strategies to reduce postharvest pear decay. Tree Fruit Postharvest J. 6:13-14.

27. Sugar, D., and Spotts, R. A. 1999. Control of postharvest decay in pear by four laboratorygrown yeasts and two registered biocontrol products. Plant Dis. 83:155-158.

28. Wade, M. 1988. Strategies for preventing or delaying the onset of resistance to fungicides and for managing resistance occurrences. Pages 14-15 in: Fungicide Resistance in North America. C. J. Delp, ed. American Phytopathological Society, St Paul, MN.

29. Yourman, L. F. and Jeffers, S. N. 1999. Resistance to benzimidazole and dicarboximide fungicides in greenhouse isolates of Botrytis cinerea. Plant Dis. 83:569-575. 